\title{
Cuba and Brazil: An Important Example of South-South Collaboration in Health Biotechnology
}

\author{
Tirso W. Sáenz DrSc, Halla Thorsteinsdóttir DPhil, Maria Carlota de Souza PhD
}

\begin{abstract}
SUMMARY
This article analyzes the entrepreneurial cooperation between Cuba and Brazil in health biotechnology. It looks at the strategies applied and the main impacts. The respective government/ political wills and the corresponding South-South collaboration policies are discussed, as well as the steps taken to materialize collaboration programs, including joint production of a meningitis vaccine for Africa. This cooperation is a good example of how South-South collaboration can be a useful tool to promote capacity building and provide cost-effective health solutions for developing countries.
\end{abstract}

KEYWORDS: Biomedical technology; technology transfer; technology, pharmaceutical; international cooperation; Brazil; Cuba

\section{INTRODUCTION}

Developing countries have placed increasing emphasis on SouthSouth collaboration, particularly since the latter part of the $20^{\text {th }}$ Century when many African, Asian and Caribbean countries joined the ranks of independent nations. An initial drive to cultivate and diversify markets, and move away from perceived unfavorable North-South terms of trade, later evolved into a broader sharing of common needs and clusters of common interests.[1]

In this context, developing countries have been prompted to learn from one another in order to address in a cost-effective way the many environmental, health and climatically-induced problems they face, for which developed-country solutions are not viable options. Scientific and technological innovation is now playing a greater role in such South-South collaboration, resulting in more bilateral and multilateral agreements that include these components, such as the India-Brazil-South Africa Initiative (IBSA).[2,3]

To understand better the opportunities afforded by South-South collaboration programs in science and technology (S\&T) for health, as well as the factors and conditions that shape them, a team of researchers from Brazil, Canada, China, Egypt, India and Zambia conducted a large-scale study of developing-country cooperation in health biotechnology. We used varied data sources and focused both on research collaboration (mainly between researchers at universities and public research organizations), and entrepreneurial collaboration (mainly, but not entirely, between private sector firms). To map research collaboration, we analyzed co-publications of researchers from different low- and middle-income countries. To map entrepreneurial collaboration, we conducted a survey of leading health biotechnology firms in six developing countries concerning their collaborations with all other developing countries.[4] Lastly, to understand the opportunities, challenges, and impact of South-South collaboration programs and identify strategies to strengthen them, we carried out extensive interviews with health biotechnology researchers, entrepreneurs and policymakers in 13 developing countries. We conducted a total of some 300 interviews for the study.
This article, which focuses on Cuba-Brazil collaboration, is based on case study research by the authors as a part of this megaproject. This involved interviews with researchers, entrepreneurs, institution directors, officials from ministries and government agencies in Brazil and Cuba, as well as examination of official documents and articles related to the topic.

\section{GOVERNMENTAL SOUTH-SOUTH COLLABORATION POUCIES}

Cuba is one of the few developing countries able to develop newto-the-world innovation in the science-intensive biotechnology sector and harness these innovations for improving the health of its population. An integral part of Cuban health biotechnology is a focus on local health needs and close ties between the public health sector and the S\&T system.[5-7] Cuba has prioritized investment in health biotechnology since the early 1980s and built up both human resources and innovation infrastructure, which in turn has opened a new and growing field for exports and international cooperation.[8]

To further promote biotechnology innovation, in the early 1990s Cuba created the Western Havana Scientific Pole (WHSP), a cluster of scientific research and technology institutions in the capital, similar to scientific parks in other parts of the world. It includes ten core centers, like the Center for Genetic Engineering and Biotechnology (CIGB), Center for Molecular Immunology (CIM), and Finlay Institute, as well as some 50 related research, production and marketing facilities. Linked to the WHSP are a number of hospitals, medical universities and other partners.[8,9]

Cuba's strengths in the biotechnology field are reflected in several new-to-the world innovations. Among them are: the vaccine against type-B bacterial meningitis developed by the Finlay Institute;[10] Nimotuzumab, an anti-cancer epidermal growth factor receptor currently being tested in clinical trials in several countries in consortium with YM Biosciences (Mississauga, Canada) and partners from 12 developing countries and 6 developed countries;[11] and a synthetic vaccine against Haemophilus influenzae type b (Hib).[12]

A well-defined Cuban policy promotes South-South collaboration, particularly in health delivery in low-resource settings in Africa and Latin America, and in education of health professionals from those countries, reflected in enrollment of several thousand in the Latin American Medical School (ELAM, its Spanish acronym) in Havana.[13,14] In science and technology, by 2008 Cuba had agreements with 32 developing countries: 13 in Latin America and the Caribbean, 12 in Asia and 7 in Africa.[15] It had only 11 agreements with European countries, Canada and Australia, indicating a stronger emphasis on collaboration with countries in the global South. In Cuba's cooperation with Brazil, India, Iran and China, biotechnology cooperation is particularly emphasized. 
Brazil, the $10^{\text {th }}$ largest economy in the world, has experienced significant economic growth and as a result is considered an "emerging economy".[16,17] It has a relatively long history of supporting science and technology and, in recent years, resources for S\&T have increased both from public and private sources. In 2003, 1.3\% of Brazil's Gross Domestic Product (GDP) was invested in science and technology; by 2008 , $1.4 \% \cdot[18,19]$

Since the late 1970s, different governments in Brazil have prioritized biotechnology in their efforts to promote knowledge-intensive development in the country. As a result, considerable capacity has been built in health biotechnology, including well-equipped research institutes and an evolving private sector that has started to pursue both process and product innovation.[20,21]

Brazil ranks third among low- and middle-income countries judged by number of papers in health biotechnology published in international peer reviewed journals. Brazil and South Africa top other leading developing countries in the sector in publication of their research in relatively high-impact journals.[22]

The public research institutions-the Oswaldo Cruz Foundation (FIOCRUZ, Rio de Janeiro) and the Butantan Institute (Sao Paulo) - together with some universities are the main actors in the health biotechnology sector. FIOCRUZ, attached to the Ministry of Health, is one of the most prominent health S\&T institutions in Latin America. Promotion of health and social development are institutional core values. Bio-Manguinhos, FIOCRUZ's production unit, is one of the largest suppliers of immunobiological products for Brazil's National Immunization Plan.

The country's main successes in new-to-the world innovations for health include development of new technologies for production of vaccines against yellow fever and small pox, as well as recombinant insulin.[20] Brazilian researchers are currently involved in the world's largest clinical trial on stem cell therapies, the MiHeart Study, a multi-institutional collaboration examining their safety and efficacy for cardiovascular disease.[23]

During the last two decades, Brazilian governments have promoted South-South cooperation in S\&T, spearheading programs for collaboration within Latin America, with Portuguese-speaking African countries and more recently with other emerging economies. Among the main collaboration programs are:

- CABBIO, a joint program with Argentina in biotechnology established in 1987.[24]

- MERCOSUR, an economic block created in 1991 by Argentina, Brazil, Paraguay and Uruguay to eliminate tariffs and commercial restrictions on their products. Bolivia, Chile, Colombia, Ecuador, Peru and Venezuela are associate members. MERCOSUR has begun supporting S\&T collaboration.[25]

- PROSUL, the South American Program to support S\&T cooperation in the region.[26]

- PRO AFRICA, a thematic S\&T program with African Portuguese-speaking countries.[27]

- IBSA, a trilateral development initiative among India, Brazil and South Africa to promote South-South cooperation and exchange. Established in 2003, IBSA includes a focus on support for S\&T collaboration among participating countries.[28]

\section{CUBA-BRAZIL ENTREPRENEURIAL COLLABORATION IN BIOTECHNOLOGY}

Start-Up S\&T cooperation between Cuba and Brazil began in the 1990s, when several missions were exchanged to analyze, identify and discuss potential cooperation and define fields of common interest. One of these fields was biotechnology. The driving force for this cooperation was an analysis of market factors, determining which products developed, produced and marketed by Cuba were of immediate demand and economic interest in Brazil. In particular, Cuba's innovations in development and marketing of effective biotechnology products, coupled with Brazil's social and economic need to reduce dependence on imports, led the two countries to initiate negotiations on technology transfer of biotechnology products.

The main opportunities initially identified for collaboration included the following Cuban products:

- Interferon alpha $2 \mathrm{~b}$, a recombinant protein used extensively as an antiviral or anti-neoplasic agent, particularly against hepatitis C, developed and produced by CIGB.

- Recombinant human erythropoietin (rHuEPO), a therapeutic product used for treating anemia associated with chronic kidney disease, HIVIAIDS and antiretroviral treatment, chemotherapy, and other conditions; developed and produced by CIM.

Continuation Technology transfer negotiations for interferon alpha $2 \mathrm{~b}$ were started by Heber Biotec, the export enterprise linked to CIGB; and for rHuEPO by CIMAB, the entrepreneurial arm of CIM. Bio-Manguinhos was the primary negotiating partner on the Brazilian side. Cooperation was thus established between public institutions in both countries, with Bio-Manguinhos responsible for supplying products to the public market through Brazil's Unified Health System.

The basic idea was to implement a gradual process of technology transfer that would first solve the immediate Brazilian need for these products and, over time, would build Brazil's capacity to produce them. The process for both products involved the following steps:

1. Supply of packaged finished Cuban product to Bio-Manguinhos to be sold under the latter's trademark.

2. Supply of finished products to be packaged and sold by BioManguinhos.

3. Supply of basic ingredients, the rest of the process (packaging and sales) to be run by Bio-Manguinhos.

4. Complete technology transfer, with Cuba receiving a royalty.

For each step, Cuba provided the necessary documentation, training, and technical assistance to Brazil. One important result was to lower prices of these products, making them more immediately accessible to the public, and enabling significant savings for the Brazilian public health system. According to interview evidence, the international market price of 2000 units of EPO is US\$50, but through collaboration with Cuba, Bio-Manguinhos can now produce the same quantity for only US\$3.

Other important projects are being carried out, including one between Eurofarma Laboratórios (Sao Paulo) and CIM to conduct clinical trials on Nimotuzumab, a new Cuban biotechnology product 
used to treat several types of cancer. This marks the start of cooperation by Brazilian private firms with Cuban institutions in the field, an experience meriting further analysis when more information is available on the results obtained.

Cooperative Production of Meningitis Vaccine for Africa Cuba and Brazil's collaboration in manufacturing a meningitis $A C$ vaccine for African countries is a good example of South-South collaboration that reflects solidarity with other developing countries. It demonstrates how such collaboration can be harnessed to address a health threat spurred by demand and funding from an international organization.

The World Health Organization (WHO) reacted to an outbreak of Neisseria meningitidis serogroup A in Africa by assessing the status and production capacity of polysaccharide vaccine manufacturers worldwide.[29] This examination identified BioManguinhos, in collaboration with the Finlay Institute, as suitable suppliers. The resulting collaboration drew on the strengths of the two institutions' experience: the Finlay Institute in meningitis vaccine development and technology (responsible for the world's first effective meningitis $B$ vaccine), $[6,10]$ and Bio-Manguinhos in the lyophilisation processes necessary for vaccine scale-up and manufacture. The joint effort permitted a fast positive response to WHO's call and distribution of this vaccine by WHO in various African countries. According to the Finlay Institute, between 2007 and 2009, some 19 million doses were produced and distributed in Burkina Faso, Ethiopia, Mali and Nigeria. The vaccine's price is much lower than on the international market and lower than would be possible without Cuba-Brazil cooperation.

Cooperation between Regulatory Agencies To support the joint efforts of the Finlay Institute and Bio-Manguinhos, regulatory agencies in the two countries started working together. Because of the WHO's role in the Africa meningitis projectincluding prequalification of the meningitis $A C$ vaccine-these agencies were given an extra push to collaborate and had more funding available for this purpose than they would have had otherwise.

In early 2008, the two governments signed a formal agreement, stipulating that Brazil's Agência Nacional de Vigilância Sanitária (ANVISA, its Portuguese acronym) and Cuba's Government Center for Quality Control of Medicines (CECMED, its Spanish acronym) exchange documentation and site visits, and work towards harmonizing regulatory processes. As a result, these agencies created an Inter-Institutional Regulatory Commission. This cooperation has already led to increased clarity about each other's systems.

\section{CONCLUSIONS}

Entrepreneurial cooperation established between Cuba and Brazil in health biotechnology is a good example of South-South collaboration that can be a useful tool for promoting capacity in science-intensive fields, and for producing social and economic benefits in developing countries. Results have been positive for both sides: Cuba has been able to transfer its technologies under favorable terms, and Brazil has been able to supply important biotechnology products to its national public health programs. The collaboration has also increased availability of cost-effective meningitis prevention in Africa.
Based on our analysis, the collaboration between the Cuban WHSP institutions with FIOCRUZ/Bio-Manguinhos in Brazil has been successful for several reasons:

- Political will of the Cuban and Brazilian governments. If true cooperation is intended, it must involve relationships of trust between partners. Government action can be important in securing reliable and legitimate knowledge and technology transfers, and ensuring that proper intellectual property rights are respected. Our wider research project on South-South collaboration in health biotechnology also shows that the role of government is important for achieving local impact, putting to use capacity built through joint endeavors. In this case, the two governments wanted to work together in the health biotechnology field, based on mutual interests and solidarity with other developing countries.

- Clearly defined objectives and paths for technology transfer. The two countries identified areas where their collaboration would be beneficial in terms of capacity building and public health. Their joint analysis of Brazil's immediate need for biotechnology products to support its public health system and Cuba's ability to fulfill these needs drove the collaboration. Based on this analysis, technology transfer processes were devised to gradually build corresponding productive capacities in Brazil.

- Synergy from complementary expertise. In the case of the meningitis vaccine for Africa, each country provided different pieces of the puzzle, and together they were more successful than they would have been by themselves. A number of examples in the wider study also reinforce the notion that developing countries have an increasing range of opportunities to contribute complementary expertise to joint programs, and that cooperation strengthens their potential to develop and manufacture health products.

\section{- Priority accorded to finding appropriate solutions to local} health problems. This was certainly a driver for the CubaBrazil collaboration, particularly the need to come up with less expensive products than those available on the international market. This was also a strong message from the wider study on South-South collaboration. Developing countries frequently share health problems different from those in developed countries, including different patterns of tropical and other infectious diseases for which relatively few funding sources are available. South-South collaboration in health biotechnology is therefore a powerful means to generate appropriate health products well aligned to developing countries' health needs and financial resources.

- Active participation of regulatory agencies from both countries. Our wider study on South-South collaboration showed how immature regulatory systems or vastly different regulatory processes can hamper collaboration. Such systemic attributes of health biotechnology innovation systems can either promote or impede collaboration.

Even though we emphasize the importance of South-South collaboration in this article, we are not implying that North-South collaboration has no value for developing countries. The opposite is true, since the North is still dominant in science-intensive fields such as 
health biotechnology and can be of paramount importance to developing countries in gaining access to expertise and to Northern markets for their products. However, our intention is to highlight the increasing role of South-South collaboration in health biotechnology as more developing countries enter the field. Such cooperation can also be a cost-effective way of building capacity and providing health solutions that international agencies and philanthropic organizations should pay attention to in their efforts to promote global health. To cultivate South-South collaboration, developing countries need political will, confidence in the capacities of Southern countries, and a commitment to helping each other.

\section{ACKNOWLEDGMENTS}

The authors want to thank all the experts in Brazil and Cuba who generously shared their expertise and time. We thank the reviewers for useful comments on the manuscript. This project was funded by the International Development Research Centre and by Genome Canada through the Ontario Genomics Institute. It was supported by the Center for Sustainable Development, University of Brasilia and by the McLaughlin-Rotman Centre for Global Health, an academic center at the University Health Network and University of Toronto. Dr Thorsteinsdóttir is supported by a Canadian Institutes of Health Research New Investigator Award.

\section{References \& Notes}

1. Rath A, Lealess S; Policy Research International Inc. The Forum on South-South Cooperation in Science and Technology: An Overview Document. Seoul; 2000 Feb. p. 77

2. Hassan MH. Building Capacity in the Life Sciences in the Developing World. Cell. 2007 Nov 2;131(3):433-6.

3. Mokoena R. South-South co-operation: The case for IBSA. South African Journal of International Affairs. 2007 Winter-Spring;14(2):125-45.

4. Thorsteinsdóttir H, Melon CC, Ray M, Chakkalackal S, Li M, Cooper JE, et al. South-South Entrepreneurial Collaboration in Health Biotech. Nat Biotechnol. 2010 May;28(5):407-16.

5. Lage A. Connecting immunology research to public health: Cuban biotechnology. Nat Immunol. 2008 Feb;9(2):109-12.

6. Thorsteinsdóttir $\mathrm{H}$, Sáenz TW, Quach U, Daar AS, Singer PA. Cuba - innovation through synergy. Nat Biotechnol. 2004 Dec. 22; Suppl:DC19-24.

7. Lage A. Connecting Science to Population Health: The "Closed Loop" Approach. MEDICC Rev. 2007;9(1):48.

8. Sáenz T. The path to innovation: the Cuban experience. International Journal of Technology Management and Sustainable Development. 2008 Dec;7(3):205-21.

9. Evenson D. Cuba's Biotechnology Revolution. MEDICC Rev. 2007;9(1):8-10.

10. Sotolongo F, Campa C, Casanueva V, Fajardo EM, Cuevas IE, González N. Cuban meningococcal BC vaccine: Experiences and Contributions from 20 Years of Application. MEDICC Rev. 2007;9(1):16-8.

11. Saurez G, Cabanas R, Zaldívar M, Garnier T, Iglesias B, Piedra $P$, et al. Clinical Experience with Nimotuzumab in Cuban Pediatric Patients with Brain Tumors, 2005 to 2007. MEDICC Rev. 2009;11(3):27-33.

12. Vérez-Bencomo $\mathrm{V}$, Fernández-Santana $\mathrm{V}$, Hardy E, Toledo ME, Rodríguez MC, Heynngnezz L, et al. A Synthetic Conjugate Polysaccaride Vaccine against Haemophilus Influenzae Type b. Science. 2004 Jul 23;305(5683):522-5.
13. Cooper RS, Kennelly JF, Ordunez-Garcia PO. Health in Cuba. Int J Epidemiol. 2006;35(4):817-24.

14. Blunden M. South-South Development Cooperation: Cuba's Health Programme in Africa. International Journal of Cuban Studies. 2008 Jun;1(1):1-11.

15. Interview evidence with CITMA, Ministry of Science, Technology and the Environment, Havana, Cuba.

16. World Development Indicators Database: Gross Domestic Product 2008. World Bank.

17. Organisation for Economic Co-Operation and Development (OECD). Globalisation and Emerging Economies [Internet]. Policy Briefs. 2009 Mar;8 p. Available from: http://www.oecd.org/ dataoecd/35/34/42324460.pdf

18. Petherick A. High hopes for Brazilian Science. Nature. 2010 Jun 10;465(7299):674-5.

19. Ministry of Science and Technology (BR). Brasil: Dispêndio nacional em ciência e tecnologia (C\&T)(1), 2000-2008 [Internet]. Brasilia: Ministry of Science and Technology (BR); c2008 [updated 2010 Jun 7; cited 2008 Jul 28]. Available from: http://www.mct.gov.br/index.php/content/ view/9058.html

20. Ferrer $M$, Thorsteinsdóttir $H$, Quach $U$, Singer PA, Daar AS. The scientific muscle of Brazil's health biotechnology. Nat Biotechnol. 2004 Dec;22 Suppl:DC8-12.

21. Rezaie R, Frew SE, Sammut SM, Maliakkal MR, Daar AS, Singer PA. Brazilian health biotechnology - fostering crosstalk between public and private sectors. Nat Biotechnol. 2008 Jun;26(6):627-44.

22. Thorsteinsdóttir $\mathrm{H}$, Archambault E, Aranachalam S, Daar AS, Singer PA. Health Biotechnology Publishing Takes-Off in Developing Countries. Int J Biotechnol. 2006;8(1/2):23-43.

23. Tura BR, Martino HF, Gowdak LH, dos Santos RR, Dohmann HF, Krieger JE, et al. Multicenter randomized trial of cell therapy in cardiopathies MiHeart Study. Trials. 2007 Jan 18;8:2.

24. See CABBIO- Centro Argentino Brasileño de Biotecnología, http://www.mincyt.gov.ar/cabbio2.htm
25. See MERCOSUR, Mercado Común del Sur, http://www.mercosur.int

26. See PROSUL, http://www.cnpq.br/editais/ct/2008 /011.htm

27. See PRO AFRICA, http://www.cnpq.br/editais/ $\mathrm{ct} / 2008 / 012$.htm

28. See IBSA, http://www.ibsa-trilateral.org/

29. World Health Organization. Meningitis in Africa: Hundreds of thousands vaccinated [Internet]. Geneva: World Health Organization; 2007 March 16. [about 3 screens]. Available from: http://www. who.int/mediacentre/news/notes/2007/np12/en/ index.html

\section{THE AUTHORS}

Tirso Walfredo Sáenz Sánchez (Corresponding author: tirso@onix.com.br), chemical engineer. Associate researcher, Centro de Desenvolvimento Sustentável, Universidade de Brasília, Brazil.

Halla Thorsteinsdóttir, doctorate in science and technology studies. Associate professor, Dalla Lana School of Public Health, University of Toronto, McLaughlinRotman Centre for Global Health, University Health Network \& University of Toronto. Toronto, Canada.

Maria Carlota de Souza Paula, political scientist. Associate researcher, Centro de Desenvolvimento Sustentável, Universidade de Brasília, Brazil.

Submitted: May 3, 2010

Approved for publication: July 12, 2010

Disclosures: None 